\title{
Corona Virus: Eating up the Brain of the Society
}

\author{
Tasmima Sabatina ${ }^{1, *}$ \\ ${ }^{1}$ Department of International Relations, University of Dhaka, Dhaka, Bangladesh \\ *Correspondence: Department of International Relations, University of Dhaka, Dhaka, Bangladesh. E-mail: \\ tasmimasabatina20@gmail.com
}

Received: September 7, $2021 \quad$ Accepted: September 26, $2021 \quad$ Online Published: January 10, 2022

doi:10.5430/wjss.v9n1p1 URL: https://doi.org/10.5430/wjss.v9n1p1

\begin{abstract}
Covid-19 confinement has changed students, learners and even teachers to alternate their learning strategies and testing the efficiency and assessment process overall. Using both primary and secondary data from online authentic sources and field research by taking school-going students and undergrad students as sample, this paper examines the regular struggles and obstacles, that the learners had to face due to this pandemic. Both teachers and students had ti perform numerous combats to get victory over quality education. The second correspondents were HSC students of Bangladesh, especially, batch 2020. And the result shows that there is significantly negative impact which greatly makes the next generation brainless and no doubt, are jn great danger, as they are not only going to be the next future leaders but they will be the policy-makers of the nation. Additionally, the paper also focuses on the decisions taken by government and the possible results regarding education system of Bangladesh.
\end{abstract}

Keywords: Covid-19. pandemic, distant learning, education, teaching, institutions, developing country, job market, economy

\section{Introduction}

The year 2020, had started its journey with a staggering world pandemic which had kept the mankind at a standstill for months, and now the time period has exceeded to years. Covid-19 pandemic, a global outbreak has crossed boundaries of world map in terms of spreading. It's impact and affect has caused to the countries to announce immediate responsive care and to change lifestyles of millions of people being forced to 'stay at home and to stay quarantine'. In recent years, the World Health Organization (WHO) said the predominant lineage B.1.67 was first identified in India last December, although an earlier version was spotted in October 2020. "There is increased transmissibly demonstrated by some preliminary studies," Maria Van Kerkhove, WHO's technical lead on COVID-19, said on May 10 , adding that more information is needed about the Indian variant to understand how much of it is circulating. (Kumar, 2020). The global pandemic has not hampered the daily lines of people but also has increased the gaps between overall growth of economy and education. The virus has kept human life ineffective and impractical in terms of performing and following daily routine. Although the COVID-19, the virus had spread in China, approximately in the month of December, 2019. From some unauthentic news and sources the confirmation of the virus got detected. However, the presence of this virus particularly in Bangladesh, it got into news in the month of March, 2020. From some scattered news data information, and cases proved that the virus make up the most vulnerable group in children, younger and adults who are more than 60 above in age. The first 3 cases have identified in Bangladesh on March 8 (2020) by the institute of Epidemiology, Disease Control and Research. Two of the three affected then recently returned home from Italy. Since the number of affected people increased periodically, the government announced lockdown throughout the country from March 26 to April 4. At the end of April, the rate of new infectious began to rise very rapidly. Bangladesh, in response to corona virus, with almost every country adopting aggressive non-therapeutic measures to control the spread of COVID-19, it has also followed the same trend.

Now if we shift the attention from world pandemic to pandemic and education, we can see that our future generation are at stake. Schools, colleges and universities all over the world had to be closed for safety reasons. Without any doubt and debate it can certainly be stated that numerous universities and educational institutions of the globe have remained closed due to this pandemic. And the impact of these incidents are both academic and social. Academically, the most 
hampering effect is delaying in lesson coverage and inadequate knowledge received by the students. On the contrary, socially, we can see the inefficiency in quality education resulting fail educate taskforce in job sector. With this sudden changes and shift away from the classroom in many parts of the globe, students, teachers and guardians are concerned about the result of online education. In the context of Bangladesh, it has been approximately 7-8 months that all educational institutions are closed, due to which, many teachers have lost their jobs. There is some news that teachers had switched their profession with a view to meeting up their financial needs.

\subsection{Research Question}

As we already know that education is one of the basic rights of human but due to the outbreak of pandemic, education is no freer or less costly. Rather it has become costly. To continue the online platform, there are many students who are unable to afford the cost of gadgets, data plan or Wi-Fi connection. There has now more inequalities between privileged and non-privileged families and students alongside. Students who are special, and physically challenged, they are impoverished due to this online platform, and mainly due to this pandemic. Children who are living in extreme poverty are not getting any benefit from this e-learning. Same scenario can be depicted on those children who are engaged to child labor but at least getting the advantage of free schooling by the government and many other private NGOs. This pandemic has left the whole mankind vulnerable but also by keeping in mind the question that arises here, "Is the Pandemic eating up the brain of the society?"

To answer this question, it can be said that the pandemic has threatened the nation in terms of having an equal and quality of education. It has become a doubt, whether the quality of education will be got by the students through online education. And even if it will be served, then what about the non-privileged students and special children and their education. It is surely making the whole nation way step behind because of the year gap in education system. Not only the school going students, the students who wanted to pursue their higher studies in abroad, they have lagged behind because of the restriction and banned in different countries because of the pandemic. Reports has shown that at different times, government has taken and rescheduled the time of different examinations which has adversely hampered all students' type, from kindergarten to university going students.

\subsection{Literature Review}

Literature review, as demonstrated below shows the research gap, with a view to establish the claim that the focus of the present study is different from other existing work.

David Kvavadze (2020) explored and studied about the capacity and population of the countries to continue education process at the schools in the online form of distance learning. In the research work, the authors completed a case study about how far the online education program is effective and the results shows that the quick transition to the online form of education went successful and gained experience that can be used in the future.

Pradeep (2020), in the journal he examined and highlighted the impact of the terrible COVID-19 outbreak on the education. The author also explained about the mental health issue, examination and assessment process, travel restrictions on international conference and meetings.

John (2020) stressed on higher education and coronavirus situation particularly Ghanaian international students in China. He identified that almost all the convocations and graduations had been cancelled, classes had been cancelled, and examinations had been postponed. It also described about the internet cost and slow internet cost, the students less quality of education.

From all these arguments and articles, all the authors and writers have concluded either on the success of online education system or the disadvantage and negative impact of online system e-learning. But they did not focus on the point that education has only become a product for privileged community. It is not available for all at all. Moreover, they have not spoken about the disable and special children students and their education, or the students who live under poverty line and cannot afford the least education because of this pandemic.

\subsection{Contribution of the Study}

Corona pandemic has become a part and parcel of our life now. We have to struggle and survive in this amid situation. Education today is in crisis. It is not only the scenario in Bangladesh that students are temporarily out of school and all other educational institution, it has estimated that the world is at stake now, and have taken immediate actions in closing down all institutions, including educational institutions. Quality education is arguably one of the most vital element of life, but there are many group of students who are missing out on the education needed to live fulfilling lives as adults and to participate in the mankind. This paper is mainly focused on to discuss about the ongoing impact of the pandemic on education system as a whole, the measurement of special child's education, the future impact of skill 
achievement, education of those children who are engaged with child labor. It has focused to discuss how the pandemic is hampering the education life, and an overall discussion of its aftermath.

In recent times, the Bangladesh Government has declared to hold the HSC (Higher Secondary Certificate) and equivalent examinations. Not only that, the government also announced that the HSC results will be evaluated based on the students' JSC and SSC results and their average. This decision has been taken under the light of ongoing corona pandemic. This paper is mostly focused on the quality education that students are getting through online classes and the assessments that the faculties are taking, how far it can actually be convenient to the nation and society. The least potential that our students had, the pandemic has pulled down the hope here because of the constant lockdown and delaying of conducting classes and assessments. Therefore, I want to stretch the points for instance, the serious impact of the lockdown of all educational institutions, and about the quality of education that our students are getting through online assessments and classes, what are the future implications that these students can contribute in the society. These are some of the factors that I am going to explain through this paper.

\section{Methodology}

For conducting the study, basically the quantitative research methodology is going to be applied to collect necessary data from both primary and secondary resources. Additionally, the collected that will be analyzed and the results will be interpreted theoretically and is going to be critically analyzed concerning the earlier researches and studies that are relevant to this one. The data and information were collected through secondary sources such as research papers, government policy, government reports, newspapers, online blogs, books, online opinion articles, etc. The target population comprised from school going and university going students of Dhaka district and students who were recent University students, at least 18 years old. The respondents were selected through online communication portal via social media and had taken participation in sampling method by advertising on University online group and posts.

This is a qualitative case study focused on Bangladesh based on both primary and secondary data. An e-questionnaire was prepared by Google form, in an online-based platform to the students, and other participants. It is a questionnaire-based observational study conducted on the students of a reputed English medium school, Honors (Department of Computer Science and Engineering) and Masters (Department of English and Humanities) students of BRAC University, Bangladesh. The study period was from October to December 2020. The classes of BRAC University were conducted by university's own online learning platform that is built on a world-class platform developed by MIT and Harvard, which capable to count attendance involuntary. Therefore, class percentage (\%) of attendance has been counted easily. The questionnaire was both close and open-ended. The answer options were yes/no, and then why yes or no? $100(50+50)$ students from engineering department of $2^{\text {nd }}$, 3rd year and MA in English and Humanities (ENH) were selected. Students from a reputed English medium school has been selected purposively as the author has direct involvement as a course teacher there. Besides, the author has an opportunity to observe them closely and realize their problems and opportunities as an observer and meeting host while taking online classes. The Snowball sampling technique was used for collecting information from students. The respondents were asked to share the e-questionnaire with their friends by using their personal and institutional Facebook and Messenger. The secondary data were collected from review of literature for instance published journal articles, newspaper reports, and online publications through internet browsing.

\subsection{Study Area}

For this research, I have only enthralled the students and all educational intuitions, from kindergarten to university going students. The online survey was done through interviewing the teachers from different schools, guardians of special children, parents of school going children, children from different classes, HSC candidates and undergraduates who are aspiring for higher education in abroad.

\subsection{Primary Data}

Primary data collection can be from multiple sources. One of the most important sources are the school, college and university going students, who are now engaged with online education platform. Another source of information can be the guardians and teachers of different educational institutions, including guardians and students of special children and non-privileged group. In addition to this, content analysis methods will be followed to analyze the collected information. To do the research on students and guardians, the method of purpose sampling can be applied to collect data. And to analyze the content data, credible resources like government and international documents, events on pandemic, education and assessment criteria etc. will be gathered and drafted. 


\subsection{Secondary Data}

For secondary data collection the study will consult sources like books, journals and thesis papers published online based on the relevance to the topic. The secondary data will provide information of the previous researches related to this topic. The secondary data will provide information will help to uphold the main argument in the thesis.

\subsection{Data Analysis}

Questions about their learning and understanding through online classes, about their mental health and the effectiveness of this type of education. Primary and secondary data and materials have been reviewed and analyzed with a view to considering the long term impact on children and overall student community in response to this global pandemic. Possible strategies, premises and a critical analysis have been made which led to the conclusion about the process of weakening school platform due to the online base education. It also generates the pre-existing weakness of school system and shortcomings which has been highlighted in the dominant pandemic situation. Discussing and analyzing the longer term effect of the quality education of the children and students.

\section{Severe Impacts/Results}

As it is mentioned before that closing down of educational institutions have been a potential damage to the education of a generation. On the other side, to think of some positivity, educationists and policy makers could also get the chance to renovate the idea of digital technology in education system through the online platform. The outbreak of Coronavirus negatively affected educational activities worldwide. According to UNICEF, in South Asia, almost 430 million children are affected by school closures and are at risk of dropping out of the education system due to the economic impact on their families. It resulted different aspects of life overall. Not only students who got affected in this, but also the teachers who had to change their profession due to the closure of schools. Again economic factor is correlated with education, in terms of teacher's salary to student's pay check. And again the online classes and resources which is sort of a burden to many families in Bangladesh.

\subsection{Impact on Educational Institutions}

In the past world history, there was no indication of education system being stopped or closing down due to natural calamity or pandemic. It is the first time ever in the world history where people witnessed the tragic consequences. More than 1 billion children are at risk of falling behind due to school closures aimed at containing the spread of COVID-19.

Educational institutions all over the world are exploring and experimenting ways to allow least education to take exemption with the unprecedented education policies. The global education system have already taken initiatives using technologies such as Internet, zoom meeting and Google classroom. Whereas, the scenario is different in Bangladesh. The closure of education institutions have just made both the teachers and students in a difficult mode. As a middle-income country, the network coverage is limited and the accessibility of devices and internet is comparatively poor. It has become almost an impossible task to apply the remote learning policy in education platform. From the primary survey and stems of UNESCO-UNICEF, World Bank, it has been reported that at least 463 million students around the globe remain cut off from education due to mainly remote learning policy and lack of equipment needed for learning at home.

In response to the unprecedented educational challenges created by school closures due to the COVID-19 pandemic, more than 90 per cent of countries have implemented some form of remote learning policy. This factsheet estimates the potential reach of digital and broadcast remote learning responses, finding that at least 463 million students around the globe remain cut off from education, mainly due to a lack of remote learning policies or lack of equipment needed for learning at home. This data primarily stems from the UNESCO-UNICEF-World Bank Survey on National Education Responses to COVID-19 School Closures (June-July 2020), as well as household microdata from sources like Multiple Indicator Cluster Surveys (MICS), Demographic and Health Surveys (DHS). (Setiawan, 2019)

These are the estimation of different surveys and data collection. Educational institutions closing indicates the very alarming day of nation's fall. It clearly signifies the suffering of not only the students but also for the teachers. Reports had confirmed that many teachers from Dhaka city had shifted their professions due to no payment of schools. This news is quite frightening as teachers are the pillar of a society. Therefore, switching their profession specify the very future generation of itself. According to Dhaka Tribune news report, "The school is closed, and parents are unable to pay tuition, but we still need to pay Tk80,000 for monthly rent. The teachers and staff of the school are struggling every day," said Dolly, founder and director of the school. "We have not been able to pay even Tk10 to the teachers and staff 
as there are no funds," said Dolly. Most teachers of the Little Stars Preparatory School in Pallabi have returned to their village homes to try and find a way to earn a living as the school has been closed for seven months now, said head of the school Abdul Majed Sarker. (Siddique, 2020)

Around a thousand teachers of private educational institutes, including schools, kindergartens and madrasas, in Narail had gone without pay for five months during the adverse period COVID situation which resulted teacher's unemployment and the pandemic 'forcing many teachers to change profession'.

\subsection{Impact on Primary Students}

The government has summarized a thirty-day long syllabus and decided to evaluate students with assignment work for secondary school level. Students from Grade 6 to 9 collected their assignments from the TV lessons and the website of the National Curriculum and Textbook Board (NCTB), as well as from their current school. All students have been warned by the government that if they had completed assignments using third-party guidebooks or copies from others, teachers will cancel the assignment (Alamgir, 2020b)

It is quite challenging for primary level children to cope up with the online class schedule and adopt the new technologies. It is more difficult for children of all level who were already engaged in schooling. In the policy of providing education to all means and to all level of students, along with primary students, the special children need the subsidiary care and attention as well to have their basic right of education. While government and many other private institutions have started the online platform for learning, it has become barely possible to make a room for the special children. As they need additional help and motivation in the learning process, technically it has not been possible for the teachers to give the same attention and offer same kind of motivation through online journey. Parents of special needs children have struggled through a trial and error process. They had to struggle to find what works and what does not to encourage their children to engage with virtual education. As both the teacher and parents have understood the point that in-person education looks much different than it did before COVID-19. And free contact and physical interaction is a pre-requisite for early children and primary students. As not all each of the child has the same kind of resources to access to the online classes. There are also other factors that are significant for instance, lack of administrators' training and guidelines; and difficulty scheduling lessons due to caregivers' time constraints. So here the question arise, are the students getting quality education through the online classes?

Students who were supposed to start their schooling from 2020 onwards, they had to either sit at home for further notice of school reopening or they had to start doing classes at online primary teaching policy. In one way it is a positive thing that as a developing country, we are engaging with updated teaching methods but on the contrary, as we are a developing country, most of the population are not involved in this teaching criteria and this is for both the teachers and students. It can also be mentioned here that Bangladesh government inclusive education has policy regarding primary education. On this very edge of pandemic, all these policies seemed to be invalid because of covid-19 in early 2020, Bangladesh government had declared lockdown and institutions to be closed for uncertain period of time. The learners who were under this primary education programme were all learners of all categories. Because high-quality education is crucial to young children's future success, it is important to acknowledge the role early childhood educators play in fostering children's development during the COVID-19 pandemic. (McKenna, Meaghan, et al, 2021). The future of these learners are at stake because of the year loss that students had currently experienced.

\subsection{Impact on Higher Secondary Students}

The tertiary level students, meaning the high school and college students are most likely losing their interest to overall learning procedures.

In terms of online education, it us not only focused on offering online courses, developing teaching methods and providing lessons on daily basis. There are some other influential factors related to this sector. The lessons and knowledge that the teachers have offered to the students, it is crucial to look at the students whether they are ready to receive them or nit. During lockdown situation when schools, colleges and universities were remained closed, institutions has initiated to offer courses online. However, the linear process of attending classes from face to face, to computer screen, it is indeed a tough job for the students to complete and to even continue. In recent times, according to sources, it has been estimated that 15.4 percent of the population has access to the internet and along with that, it doesn't provide high speed internet connectivity. It has become a challenge for rural students to attend the classes as many of them do not have any device even. Apart from all these challenges and obstacles, one of the big news for Higher Secondary (HSC) students were without attending the HSC exam, they were given the auto pass and it was calculated from the result of Junior School Certificate (JSC) and Secondary School Certificate (SSC) of each candidate. 
Education Minister Dr Dipu Moni has announced that the exams will not take place this year, and the candidates will be awarded based on their previous academic records. Considering the present intensity of Covid-19, and in an attempt to avoid the possible second wave of the outbreak predicted by health care specialist. Due to this covid pandemic, the intellectual loss of the students are irreplaceable and irreversible. Students had to face one year session loss due to this pandemic. This was not only the loss and damage that the students had to go through. Reports has shown in different journal articles and newspaper news that the students are facing taunts and mocking due to the auto-pass policy.

According to Dhaka Tribune news report, Humayra Haque, an HSC examinee from Holy Cross College, says: "One of my relatives said that although you are earning certificates without appearing in exams, remember you will not find any job without an interview. Several others have continuously been mocking us. It drags our mental state down." Due to this government decision, an entire generation of promising students may be left behind and facing severe issues like psychological trauma and distress. It has been unsolved and no possible solution has been given to those students who had sound preparation and aspiration for obtaining better grades despite poor marks in SSC and JSC. Higher Secondary Certificate (HSC) examination has significance for shaping up the future of each candidate as through this examination, students get the chance to decide their career path. Now many of the public university exams are now at hold, due to the sudden breakout of third wave of covid-19. Students still could not admit themselves into any university due to the suspension of all public university exams. Although several dates and notices had been issued but by the time, government had to cancel almost all of them because of the rapid uprising of COVID cases in recent year. It has become an alarming concern for the students who are aspiring to denote their future path, are now has become clueless and hopeless in a way. They are in a confusion and doubt with their certificates that they have achieved without any assessment of their knowledge. Therefore they would be questioned several times about their skill and potentiality throughout the time. The other concern is whether these HSC candidates will be able to pursue higher education abroad and whether they will be capable of competing with other international students. Cancellation of exams does not necessitate candidates to study and prepare intensively for the exam and will serve as a means of detachment with study for the candidates, which has happened to many students instead. Thus, their spirit will no longer be as strong; traditionally, students are accustomed to studying hard when the exam is close to hand. As they have already given their HSC results and admission test dates are more frequently changing every now and then, this might slow down their perseverance and attention towards studies. Although they have to sit for the biggest battle of the university admission test which is without any doubt, is considered to be the most competitive academic test in Bangladesh.

Many students have already got admitted into private universities without delaying and without waiting for government exams circular. Here the question arises, are the students getting quality education through online classes? Those who are capable of admitting themselves into private institutions, they have done it already. But those, who are in hope of getting themselves admitted into public universities, are still in a hanging position which results, depression, lack of concentration in studies and anxiety among students.

\subsection{Impact on University Students}

International experiences denote that, schools and universities are opting to continue their normal classes on online platforms. These include the use of online tools such as group video programs, group telegram that allows teachers and students to meet using mobile data and access through Internet.

Distance learning or online learning is quite popular among developed countries but as it has recently launched here in Bangladesh, it has relatively impossible to tackle a bunch of students education programme altogether. According to the questionnaire, the percentage of unmet demand of the students has increased due to the insufficiency of internet access in remote and unprivileged communities and some regions around Bangladesh. Unequal access to educational resources to different levels of students have created barriers or obstacles for the students who cannot participate in this learning process. There are numerous benefits of advanced and digital services in terms of using it in the digital mode of education but not all the students have access to a smooth internet access and other educational materials. As a result, the online learning process impacts the overall outcome of a student of a country. 
Table 1. Presentation of Data Collected from the Respondents

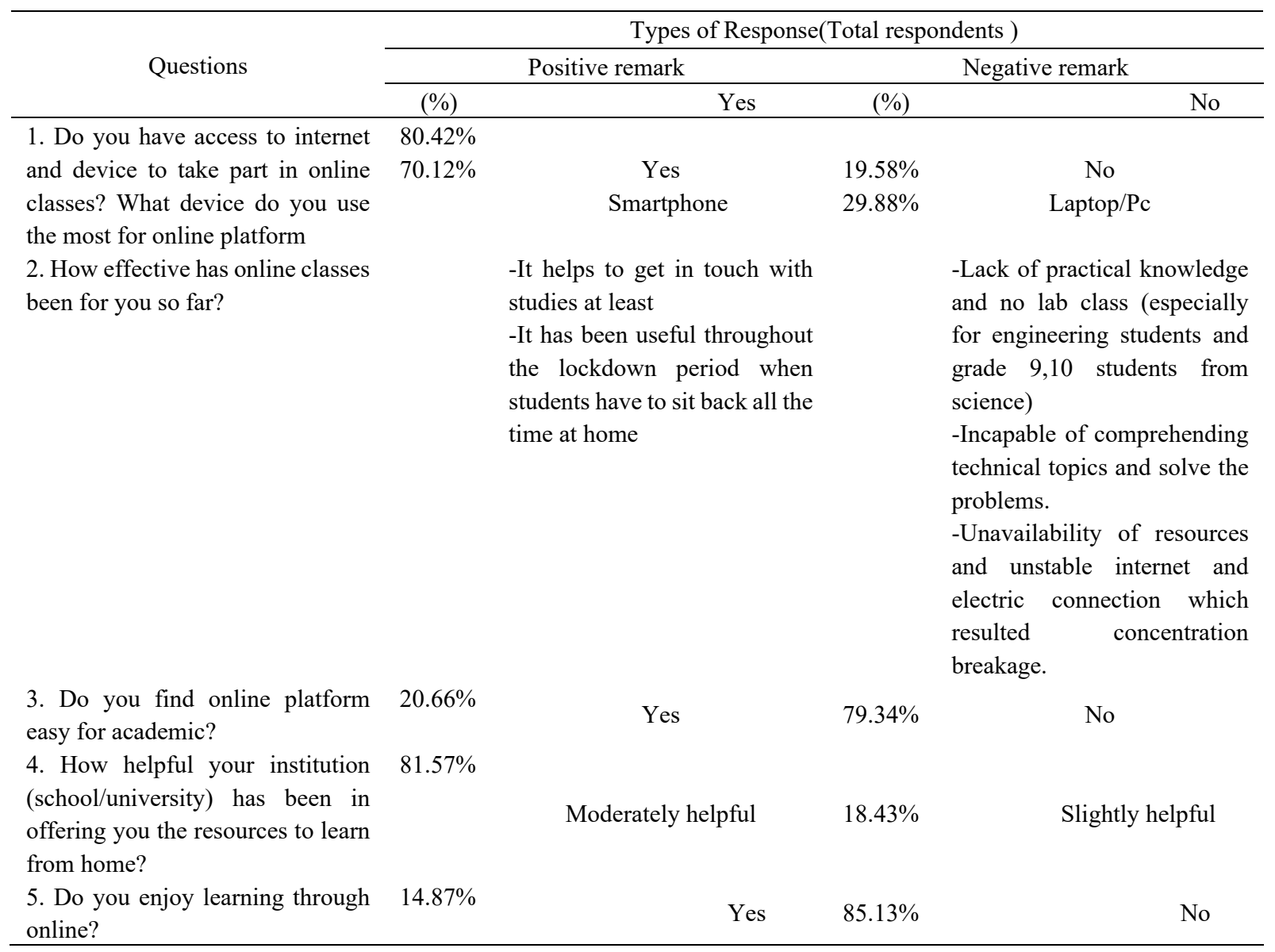

Table 1 indicates the representation of the responses of respondents about five basic questions of online higher education during the COVID-19 pandemic. In respond to each question respondents had given their answers and opinions. Some respondent stated that it is possible to attend online class without attending classroom physically; through online system social and physical distance maintain is possible; theoretical classes can be conducted and students can comprehend through online classes. As a positive remark many of them gave their opinion in a way that online higher education is keeping students busy as a result they are not affected by depression. Some school going students had also given their positive remarks to this point as well. Online classes are always better than no classes at all because they got some basic ideas and guidelines about their courses and subjects. However, $79.34 \%$ respondents had given negative remarks about online education. They considered that online classes are not beneficial for them and learning research-based higher education (for instance the students of Computer science Engineering) is not possible due to lack of laboratory practical knowledge and field work experience. Due to lack of internet and devices, most of the students were absent in the classes. Therefore, they did not find any advantages. Again, in the question of how useful are the school/university resources, most of them had voted for positive remark. Resources are available through online, so they do not have to hardcopy of the book or notes. Nonetheless, it had been beneficial to some extent to some learners only as we can see the response of the second question which stated the negative remark. Students have all the resources, but the impact that the online classes are embarking, it is not rarely positive. Students need to understand first and then apply. Especially in case of technical subjects like physics, chemistry, biology, mathematics (for school going children of grade 8 and 9). Again, in case of department of Engineering, they have to solve and learn topics from lab and extensive field work. Some of the students need to do internship to gain knowledge from practical world. Due to this pandemic, many students are deprived of such facilities which has a long term impact on these students. In the long run, without having a firm knowledge regarding their subject and courses, they will not be able to cope up with the upcoming challenge of job sector and practical work. In the third question, respondents were supposed to give a viewpoint regarding whether they find the online platform easy for academic purpose. Most of the respondents had asserted the negative remark here. They don't find online platform for learning as an easy way to access. According to 
them, major problems are that they could figure out are, as most of the courses are conducted by a specific online system like zoom or Google class or BuX so at a time very few teachers can engage in this system due to lack of strong network and internet speed. Sometimes the students get out of network or it takes a whole time to get access to the class again. Similarly, interruption of the internet due to lack of and poor broadband internet most of the students could not stay connected and listen to the whole class. It resulted the poor attendance of students than in the offline classroom. Again to refer the most significant aspect: quality education; which will lead the students ahead in the future. It is hardly serving in online platform. Some more important issues like a practical, lab test, written exam, and field visit are not possible. Even if the written test and exams had been taken, the assessment process is largely corrupted in a way because of lack of integrity and honesty. Therefore, real learning is hampered which is a big threat for a nation like Bangladesh. The last question which is related to student's mental health and psychological impact through online classes. Most of the respondents respond had shown negative remark. They rarely found online learning enjoyable. Although the positive remarks is quite competitive. As it has mentioned earlier that students see the learning opportunity by staying at home. Of course online learning process has benefits but if we consider in the long term impact on the students, it has more disadvantages than advantages. Although people have accepted online education has become a new normal. Nobody knows when exactly all the educational institutions will open. It will help students to advance their academic progress. Then again, we need to consider the long-term effect and results of these actions.

\subsection{Impact on Bangladeshi Students Who Want to Study in Abroad}

The world is at stake for the COVID pandemic which has not yet to pass. Moreover, we have seen its widespread impact in India in recent years. Globally the world is coping up with this virus. But it is not only the about the health that we should concern about, more precisely, we should consider about our mental health as well. Although things like mental health, anxiety, depression. It is not only the university students who are listed in depression especially those who were seeking and aiming to do their higher studies in abroad. Due to this pandemic from the year of 2020, many Bangladeshi students who were aspiring to complete their masters and $\mathrm{PhD}$ degree in overseas, were struck in Bangladesh. All the visa agencies and embassies had been closed for months due to the constant lockdown especially in capital city Dhaka. Student's life has been persistently in a loop. There are several reports regarding student's depression and anxiety due to this pandemic.

It is clear indication that the young generation of this era, they are being pushed into such an unpleasant situation. There are students who are aspiring for their masters and $\mathrm{PhD}$ degree in abroad, they get their acceptance before the beginning of this pandemic. Unfortunately, they got stuck due to visa and funding issues. It is an alarming point for our education sector as we are losing our potential brains of the nation. We are to strengthen our potentiality through the process of brain drain which has been taken place for years in our country. Meanwhile, a study reported that graduate students generally experience significant amounts of stress and anxiety, which also affects their usual behavior (Garcia-Williams, et al, 2014)

Particularly in Bangladesh, students are in a situation where they are in this uncertainty whether they would get the certificate or not, as such extended graduation period. It is happening especially with the students who are fresh graduates and to those who have aspired to study in abroad. In case of fresh graduates, they are in a depression state as they are draining of thinking of their near future and job opportunities. In a conventional scenario, people have to compete in a job market for better career opportunity. And this pandemic has already added a new dimension in it. Furthermore, the students who have the objective of studying abroad, they are coming unstuck in getting themselves admitted into their desired colleges/universities. Many graduates have made plans about their future and have worked according to the schedule, yet due to the pandemic crisis, applicants are in doubt that they might falling academically behind in compare to other counterparts of the world.

It is not bringing any positive outcome or result as the educational institutions and embassies are being closed for an uncertain period of time for months after months.\# It is indeed a crisis period, especially for the fresh graduates who were in hope of flying abroad in the year of 2020, now are either sitting at home or have to reschedule their future plan for upcoming year. It is both traumatizing and hectic for the students.

The nation-wide lockdown in Bangladesh has caused a significant disruption in the academic programs and created a gap in both teaching and learning. It is the same for the students who might have started their master's classes through online. Nonetheless, most of them are only attending the semester classes but the assessment procedure cannot be taken via online. Therefore they have to attend the exams on campus when they would be able to go and be present physically. By the time, each of the semester has been covered without any student assessment. It is a great deal of mental stress and anxiety for the students who have enrolled in online abroad classes for master and $\mathrm{PhD}$ degrees.

Another aspect that we can focus here is the financial factor that works for many university students in Bangladesh. 
Most of the students who enroll in university sector, are more or less depending on private tuitions, part-time jobs in companies, coaching tuitions and so on. Due to disruption of this pandemic, students cannot go outside of home for months, which result joblessness and financial insecurity. Undoubtedly fresh graduates are facing obstacles like standstill positions of their life which is indeed a negative impact for a nation like Bangladesh.

\section{Upcoming Challenges}

Undoubtedly, COVID-19 pandemic is something that has happened not only our daily lives but also our interpersonal activities. This pandemic has become a barrier for whole a generation to move forward. Before looking for solutions, we must have to identify the problems and possible effects that might occur due to the problems. We can surely say that the effect of COVID pandemic is not positive at all on education sector, rather it has negative impact and there will be negative outcome as well. Although technology and advancement has spread in this pandemic, there are challenges which are necessary to address for further solutions in education sector.

\subsection{Coping up with Online Education}

Learning and teaching opportunities have been shrunk and have become in a form of remote or distant learning. Due to the virus and in order to stop the spreading of it, many countries including Bangladesh, have adopted the online teaching and learning process. COVID-19 has been contemplated to be the most immediate aftermath of this pandemic. All educational institutions went online since March 17, 2020 and even from that period to till October, 2020, government has changed and shifted the dates of public examinations time to time and so, the students are in great unstable position. As the dates have been changing, so do the methods of evaluation, the curriculum and activities have changed. In a very simple words, not all the students can have the access to take part and attend the online classes. The survey that has been done through snowball sampling method, it has been only implied on selected group of people. On the other side if we look at the boarder picture, the scenario of developing country like Bangladesh, it rarely can adopt this type of teaching method. Although to some extent, from the year 2020 onwards, teaching method through online has been widespread due to the closure of educational institutions. Nevertheless, this changing methods and modules are not compatible with the resources. It has been estimated from sources that around 12.7 percent of households do not have a single mobile phone. Yet mobile phone is at odds, main instrument to attend online classes, is to have a smartphone, which is an indicator of unequal distribution of learning in class environment. As a developing country like Bangladesh, conducting distant learning-teaching method has become a dare to accomplish. Different institutions have adopted different platforms and mobile applications to regulate online teaching, even though both teachers and students have to make active participation in pursuance of tracking up the education process. Not all the teachers could embrace the process especially the primary school teachers and rural areas. Both teachers and students of rural areas, have struggled with coping up this new norm. The challenges that are mostly intimidating is to recreate a physical classroom to an online classroom through the power of technology and development. Through the screen, students and teachers could get the chance of exchanging views, opinions and most importantly knowledge. Although, this is not only way of how students and teachers have been coping up with this system, it has some drastic mental, ethical and social consequences that they have to overcome.

\subsection{Solving Network Issue}

Online learning provides a deal of time sufficiency, healthy routine and easy access to any resources. All these advantages are largely favorable to the learners of other countries but here in Bangladesh, establishing a wide range of network seems to be a hard task to accomplish. Distance learning provides such advantages that not everyone in Bangladesh can afford it. And therefore, government and other institutions had to take measure to conduct online base education. It is a prerequisite to set up a high speed base network connection before introducing online platform for education. This biggest question arises here that how efficiently the students and teachers can perform and adapt this new sort of method in a developing country Bangladesh. It is a necessity to be a part of online learning, students and teachers both have the essential equipment or at least a smartphone and a stable internet connection. According to daily star, Bangladesh has the slowest data connection speed among 42 countries. Where Canada enjoys $63 \mathrm{Mbps}$, we have only 7.8 Mbps. Even it was 9.2 Mbps beginning of February but at the finishing of March 7.2 Mbps. As a consequence, the uneven distribution of internet has created and increased the unequal distribution of learning. The digital divide has increased the inequity in learning platform. There is a high chance of students who are unprivileged and deprived of network supplying, would probably end up being dropped out from school, college and university even. And it is a negative coping up strategy that government should acknowledge and take necessary steps. The internet speed in the Villages is slowest. The entire attendant of the online class is 58.8 percent from private university 41.2 percent from public university. That means many of the public university students cannot afford to buy broadband internet. From the 
total candidate of online class from science $55 \%$, humanities $12.1 \%$, and social science $11.2 \%$, from business studies and other disciplines are $4.7 \%$ attending the online course. (Islam DMS, et al, 2020) A survey conducted by BioTED, a novel training and research initiative, revealed that 55 percent students do not have proper internet connections. Furthermore, presuming it to be a general holiday, many students returned to their village homes without their books and notes. Therefore, a majority of them are not being able to participate in virtual classes. Although it has confirmed by the teachers and management that in online platform, students do not necessarily have to buy the hardcopies of the books as they have already provided the soft copies in their respective sites. Even though, it is one of the very benefits of online classes that students enjoy the learning by staying at home and without any hassle. In case of students of Bangladesh, the scenario is thoroughly different. Rural students hardly get electric supply in remote places. Where electric supply is limited, internet infrastructure has become a luxury in such places to attend online classes.

\subsection{Education Gap and Job Market}

As we already know about the session break and year loss particularly of HSC batch 2020 and although their results have been published according to their previous board results, still there remains the question of integrity and skill of the candidates. There are students from schools, colleges and universities who were engaged with education but due to this pandemic, many have to drop their studies. And there are several variant behind the education gap.
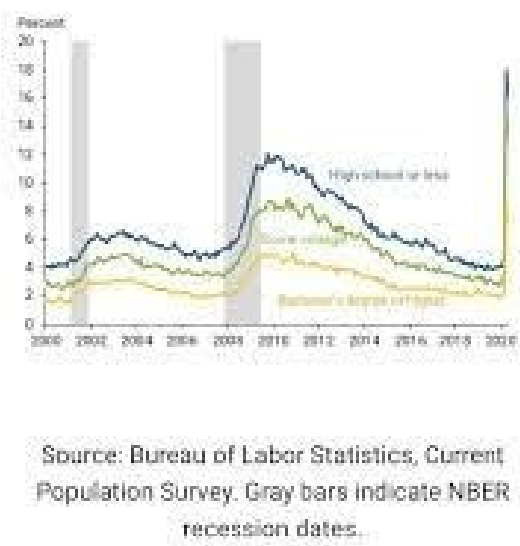

Figure 1. Unemployment by Education Level

Source: Bureau of Labor Statistics, Current Population Survey. Gray bars indicate NBER recession dates.

COVID-19. Figure 1 shows that, as the United States began widespread shelterin-place policies in mid-March, the unemployment rate spiked for workers across all education levels. However, the change in unemployment was especially large for those with a high school diploma or less. Between February and May, the unemployment rate for these workers rose by more than 12 percentage points, compared to 5.5 percentage points for those with a bachelor's degree or higher. (Daly, et al 2020)

The United States of America, one of the developed country of the world. Due to the pandemic, its economy had been drastically reversed and labor force of the system had taken a different scenario, as we can see from above. And as a developing country like Bangladesh, our economy and labor force market is in great danger. On top of that, it is alarming because education system and job market is interrelated.

The term "education gap" has different dimension of interpretation. Sessional break and jots are something that are quite familiar to the students studying in public universities. In another perspective, education gap can be depicted as "drop out" due to difficult circumstances, maybe familial hardships or financial insufficiency. However, 2020, the year has brought a curse to the whole generation particularly in education sector, as students had to give up education due to the circumstances which are beyond man-made. Education gap is directly linked with employment and it has a proportional relations between them. Students and applicants who were looking forward to pass a board exam or to apply in different companies or even to graduate, they all get caught into such a situation from where no possible solution can be provided. But we have remember that the COVID-19 pandemic has had an abrupt and drastic impact on the labor market. Through this COVID situation and aftermath of this condition is primarily a void in the job market and labor force. If we look at the industrial sector of Bangladesh, the economy has already got shook due to the 
constant and long-prolonged lockdowns. Therefore, it is no surprise of shortlisting the employees due to the crisis. To add more into this, it is also important to acknowledge that education has become costly to afford and it is no longer considered to be a basic right in this pandemic, as not everyone has got the access to utilize it. Consequently, inequality in accessing to education has become partial. Hence, it is important to keep in mind that jot everyone has the same opportunity to insulate themselves from job loss or to obtain a job instantly.

\section{Conclusion}

Many students, along with teachers and instructors are in a blow to see such social and academic changes. It is such a situation where opening and closing down of institutions carry same amount of risk and threat to the lives of public, especially to the students. This study largely intricates about the quality of education that the students are receiving through remote learning. It also focuses on the experiences of school and university going students in this pandemic who are receiving classes via online and the survey has been done through sampling research method. No wonder, developing country like Bangladesh, it has become a challenge to invest its scarce capital into public security and continue the lockdown or to invest in developing infrastructure and provide support to make digitalized education system. The strategies and policies require for online education is not adequate in terms of people's living standard and network assistance. Bangladesh needs to improvise it's strategy and tactics to adopt advance level curriculum for instance online education system. None of us knows exactly how long the COVID-19 epidemic will last. It's creating a new world that we don't know of yet, but the education sector and students must be resilient to adapt to new changes that the epidemic will bring.

\section{References}

Affouneh, S., Soheil, S., \& Zuheir, N. K. (2020). Designing quality e-learning environments for emergency remote teaching in coronavirus crisis. Interdisciplinary Journal of Virtual Learning in Medical Sciences, 11(2), 135-137.

Alamgir, M. (2020b). Primary education thru' radio set for launch tomorrow. Retrieved 27 January, 2021 from https://www.thedailystar.net/city/news/primary-education-thruradio-set-launch-tomorrow-1943081

Alston, J. M. (2020). What impact has the coronavirus had on higher education? Retrieved from https://inomics.com/insight/whatimpact-has-the-coronavirus-had-on-higher-education-1447925

Aaronson, S. R., Mary, C., Daly, W. W., \& David, W. W. (2019). Okun Revisited: Who Benefits Most From a Strong Economy? Brookings Papers on Economic Activity. Retrieved March 7 from https://www.brookings.edu/bpeaarticles/okun-revisited-who-benefits-most-from-a-strong-economy/

Ahmed, S., et al. (2021). Evaluation of Flexible Strategies to Manage the COVID-19 Pandemic in the Education Sector. Global Journal of Flexible Systems Management, 22, 81-105. https://doi.org/10.1007/s40171-021-00267-9

Anik, S. (2020). Over 500 kindergartens closed, teachers changing profession. Dhaka Tribune. Retrieved 25 September, 2020 from http://www.dhakatribune.com

Basilaia, G., \& Kvavadze, D. (2020). Transition to Online Education in Schools during a SARS-CoV-2 Coronavirus (COVID-19) Pandemic in Georgia. Pedagogical Research, 5, 1-9. https://doi.org/10.29333/pr/7937

Burgess, S., \& Hans, H. S. (2020). Schools, skills, and learning: The impact of COVID-19 on education.

Bao, W. (2020). COVID-19 and online teaching in higher education: A case study of Peking University. Human Behavior and Emerging Technologies, 2(2), 113-115. https://doi.org/10.1002/hbe2.191

Choudhury, S., \& Pattnaik, S. (2020). Emerging themes in e-learning: A review from the stakeholders' perspective. Computers and Education, 144, 103657. https://doi.org/10.1016/j.compedu.2019.103657

Chemingui, M. A. (2005). Harnessing Public Spending for Poverty Reduction in Yemen. Retrieved from www.worldbank.org/poverty/strategies.

Daly, M. C., Shelby, R. B. \& Lily, M. S. (2020). The unequal impact of covid-19: Why education matters. FRBSF Economic Letter, 17(2020).

Demuyakor, J. (2020). Coronavirus (COVID-19) and Online Learning in Higher Institutions of Education: A Survey of the Perceptions of Ghanaian International Students in China. Online Journal of Communication and Media Technologies, 10(3), e202018. https://doi.org/10.29333/ojcmt/8286

Emon, E. K. H., Alif, A. R., \& Islam, M. S. (2020). Impact of COVID-19 on the institutional education system and its 
associated students in Bangladesh. Asian Journal of Education and Social Studies, 11(2), 34-46. https://doi.org/10.9734/ajess/2020/v11i230288.

Fami, S. B. T. a. T. (2020). Is online education system suitable for Bangladesh? The Business Standard. Retrieved 11 November, 2020 from https://tbsnews.net/thoughts/ online-education-system-suitable-bangladesh-112546

Garcia-Williams, A. G., Moffitt, L., \& Kaslow, N. J. (2014). Mental health and suicidal behavior among graduate students. Academic Psychiatry, 38(5), 554-60. https://doi.org/10.1007/s40596-014-0041-y

Hossain, S., Anjum, A., Uddin, M. E., Rahman, M. A., \& Hossain, M. F. (2019). Impacts of socio-cultural environment and lifestyle factors on the psychological health of university students in Bangladesh: A longitudinal study. $J$ Affect Disord, 256, 393-403. https://doi.org/10.1016/j.jad.2019.06.001

Hassan, M. (2020). OP-ED: What does the future hold for HSC candidates? Dhaka Tribune. Retrieved 13 October, 2020 from http://www.dhakatribune.com

Islam, M. T., \& Selim, A. S. M. (2006). Current Status and Prospects for E-learning in the Promotion of Distance Education in Bangladesh. Turkish Online Journal of Distance Education, 7(1), 1-9.

Izumi, T., Sukhwani, V., Surjan, A., \& Shaw, R. (2020). Managing and responding to pandemics in higher educational institutions: Initial learning from COVID-19. International Journal of Disaster Resilience in the Built Environment, 12(1), 51-66. https://doi.org/10.1108/IJDRBE-06-2020-0054

Islam, D. M. S., Tanvir, K., Amin, D. M., \& Salman, M. (2020). Online classes for university students in Bangladesh during the Covid-19 pandemic- is it feasible? Retrieved from https://tbsnews.net/thoughts/online-classes-university-students-bangladesh-during-covid-19-pandemic-it-feasibl e-87454

Islam, Md., A \& khtarul, et al. (2020). Depression and anxiety among university students during the COVID-19 pandemic in Bangladesh: A web-based cross-sectional survey. PloS one, 15(8), e0238162. https://doi.org/10.1371/journal.pone.0238162

Kufi, E. F., et al. (2020). "Impact of corona pandemic on educational undertakings and possible breakthrough mechanisms. BizEcons Quarterly, 11(1), 3-14.

Khan, T. A. (2012). Secondary school teachers' perceptions of inclusive education in Bangladesh, Critical Literacy. Theories and Practices, 6(2), 102-118.

Kumar, S. (2020). Monitoring novel corona virus (COVID-19) infections in India by cluster analysis. Annals of Data Science, 7, 417-425. https://doi.org/10.1007/s40745-020-00289-7

Linn, M. W., Sandifer, R., \& Stein, S. (1985). Effects of unemployment on mental and physical health. Am J Public Health, 75(5), 502-6. https://doi.org/10.2105/AJPH.75.5.502

Ministry of Education. (2010). National education policy 2010. Retrieved 15 November, 2012 from http://www.moedu.gov.bd/index.php?option=com_content\&task=view\&id=338\&Itemid=416

McKenna, M., et al. (2021). Initial Development of a National Survey on Remote Learning in Early Childhood during COVID-19: Establishing Content Validity and Reporting Successes and Barriers. Early childhood education journal, 49, 815-827. https://doi.org/10.1007/s10643-021-01216-y

Mollah, Md Awal Hossain, \& Mst, S. P. (2020). Online Higher Education during Covid-19 Pandemic in Bangladesh: Benefits, Problems and Prospects. Journal of International Politics, 2(4), 23-28.

Ministry of Primary and Mass Education (MoPME) (2020). COVID-19 Response and Recovery Plan Education Sector. May, 2020. Dhaka.

Muilenburg, L. Y., \& Berge, Z. L. (2005). Student barriers to online learning: a factor analytic study. Distance Education, 26(1), 29-48. https://doi.org/10.1080/01587910500081269

Mahtab, U. (2020). Effects of the pandemic on the education sector in Bangladesh, The financial Express. Retrieved 13 June, $\quad 2020$ from https://www.thefinancialexpress.com.bd/views/effectsof-the-pandemic-on-the-education-sector-inbangladesh15 92061447

Murphy, M. P. A. (2020). COVID-19 and emergency eLearning: Consequences of the securitization of higher education for post-pandemic pedagogy. Contemporary Security Policy, 41(3), 492-505. https://doi.org/10.1080/13523260.2020.1761749 
Malak, Md. (2013). Inclusive Education in Bangladesh: Policy and Practice. Paper presented at the Annual Meeting of the Australian Association for Research in Education (AARE) (Adelaide, Australia, 2013). pp. 15. https://doi.org/10.1007/978-94-6209-692-9_9

Odo, A. I., Maigons, T. D., \& Tiri, J. F. (2020). A Threat to Nigerian Educational System: A Way Out (COVID-19). International Journal of Humanities and Innovation (IJHI), 3(3), 121-125. https://doi.org/10.33750/ijhi.v3i3.88

Pfeffer, F. T. (2018). Growing Wealth Gaps in Education. Demography, 55(3, June), 1,033-1,068. https://doi.org/10.1007/s13524-018-0666-7

Parmigiani, D., et al. (2020). E-inclusion: online special education in Italy during the Covid-19 pandemic. Technology, Pedagogy and Education, 30(1), 1-14. https://doi.org/10.1080/1475939X.2020.1856714

Pallegedara, A., \& Mottaleb, K. A. (2018). Patterns and determinants of private tutoring: The case of Bangladesh households. International Journal of Educational Development, 59, 43-50. https://doi.org/10.1016/j.jijedudev.2017.10.004

Ratten, V. (2020). Coronavirus (Covid-19) and the entrepreneurship education community. Journal of Enterprising Communities: People and Places in the Global Economy, 14(5), 753-764. https://doi.org/10.1108/JEC-06-2020-0121

Rashid, S., \& Yadav, S. S. (2020). Impact of Covid-19 pandemic on higher education and research. Indian Journal of Human Development, 14(2), 340-343. https://doi.org/10.1177/0973703020946700

Sahu, P. (2020). Closure of Universities Due to Coronavirus Disease 2019 (COVID-19): Impact on Education and Mental Health of Students and Academic Staff. Cureus, 12(4) e7541. https://doi.org/10.7759/cureus.7541

Sun, L., Yongming, T., \& Wei, Z. (2020). Coronavirus pushes education online. Nature Materials, 19(6), 687-687. https://doi.org/10.1038/s41563-020-0678-8

Siddique, A. (2020). Coronavirus: School closure forces Narail teachers to change profession. UNB. Retrieved 26 August, 2020 from http//www.unb.com.bd

Setiawan, A. R. (2020). Scientific literacy worksheets for distance learning in the topic of Coronavirus 2019 (COVID-19). EdArXiv. https://doi.org/10.35542/osf.io/swjmk

Shu, C. (2020, March 17). UNESCO updates distance-learning guide for the 776.7 million children worldwide affected by school closures $\mid$ TechCrunch. Retrieved 20 April, 2020 from https://techcrunch.com/2020/03/16/unesco-updates-distance-learning-guide-for-the-776-7-million-childrenworl dwide-affected-by-school-closures/

Ten million students told to stay home in Spain in bid to slow spread of coronavirus. (2020, March 13). EL PAIS. Retrieved from https://english.elpais.com/society/2020-03-12/basque-country-galicia-and-murcia-closeschools-in-bid-to-slowco ronavirus.html?fbclid=IwAR11_sqr1YCerswbmRvnO7UgKr9quMVvehQ9tgKdxkwtlidamgPitwIIBNM

The Dhaka Tribune (2020), OP-ED: How to make online education more effective. Retrieved from https://www.dhakatribune.com/opinion/op-ed/2020/08/26/op-ed-how-to-make-online-education-more-effective

The Daily Star. (2020). Mobile internet slowest in Bangladesh among 42 countries; 2020. Retrieved 1 August, 2020 from

https://www.thedailystar.net/business/news/mobile-internet-slowestbangladesh-among-42-countries-1892761

UNESCO: 290 Million Students Stay Home due to Coronavirus. (2020, March 7). Retrieved 21 April, 2020 from https://learningenglish.voanews.com/a/unesco-290-million-students-stayhome-due-to-coronavirus/5317148.htm 1

Uddin, M. (2020). How would the Covid-19 Pandemic affect the education sector in Bangladesh? SANEM Newsletter Thinking Aloud, 7(1), June, 2020.

Uddin, M. (2020). Effects of the pandemic on the education sector in Bangladesh. The Financial Express. Retrieved 13 June, 2020 from http://www.thefinancialexpress.com

Yogish, S. N. (2006). Education and Economic Development. Indian Journal of Social Development, 6(2), 255-270. 


\section{Copyrights}

Copyright for this article is retained by the author(s), with first publication rights granted to the journal.

This is an open-access article distributed under the terms and conditions of the Creative Commons Attribution license (http://creativecommons.org/licenses/by/4.0/). 